\title{
PERAN KESENIAN BATIK LOKAL DI SURAKARTA UNTUK MENINGKATKAN DESTINASI WISATAWAN LOKAL DAN DOMESTIK
}

\author{
Isa Maryati $^{1}$ \\ Prodi Pascasarjana Pendidikan Sejarah Universitas Sebelas Maret Surakarta \\ Maryatiisa1@gmail.com
}

\begin{abstract}
ABSTRAK
Batik adalah ikon local di Indonesia yang banyak dicari oleh masyarakat local maupun domestik. Hal ini dikarenakan batik mempunyai seni local yang tidak dimiliki oleh kain-kain pada umumnya. Motif dari batik itu sendiri mempunyai filosofi yang bagus untuk kehidupan masyarakat sehari-hari. Laweyan adalah salah satu kampung batik yang terkenal di wilayah Indonesia. Kampung ini menjadi destinasi wisata yang diharapkan mampu mendongkrak ekonomi wilayah itu sendiri. Beberapa kali penelitian dilakukan untuk meningkatkan potensi wisata di Laweyan. Sampai saat ini kampung Laweyan menjadi salah satu kampung yang di dedikasikan pemerintah untuk menjadi Desa Wisata.
\end{abstract}

\section{Kata Kunci: Batik, Laweyan, Pariwisata.}

\section{A. PENDAHULUAN}

Batik tidak dapat dilepaskan dari kehidupan masyarakat. Sejak masih ada di kandungan, lahir, remaja, dewasa menikah, berumah tangga sampai meninggal dunia, batik selalu menyertai dalam ritualritualnya. Pentingnya peranan batik ini dapat dipahami dari seringnya kehadiran batik dalam berbagai kegiatan adat, tradisi dan ritual budaya kehidupan masyarakat.

Perkembangan ilmu pengetahuan, teknologi dan seni di era globalisasi telah membawa pengaruh yang besar dalam perkembangan batik tradisional. Perubahan pola pikir masyarakat tentang proses produksi membawa perubahan inovasi dalam proses pembuatan batik. Dahulu, pembuatan batik hanya dilakukan dengan tangan, proses ini tentunya memakan waktu yang cukup lama. Perkembangan teknologi mengubah proses pembuatan batik dari tulis dan cap, lalu dilakukan dengan mesin cetak. Dalam perkembangannya, batik yang dihasilkan bukanlah kain batik, tetapi tekstil bermotif

\footnotetext{
${ }^{1}$ Mahasiswa PascaSarjana Sejarah Universitas Sebelas Maret Surakarta
} 
batik/batik printing. Batik tradisional (batik tulis dan cap) yang kaya akan nilai-nilai kearifan lokal perlu dilestarikan kepada generasi penerus agar batik menjadi tuan rumah di negara sendiri.

Dengan banyaknya peminat batik di Indonesia, salah satu daerah yang mendukung tumbuh kembangnya industri Batik adalah Laweyan. Selain sebagai Kampung tradisional, Laweyan sangat terkenal dengan julukan Kampung batik nya. Hal ini karena daerah tersebut di setiap rumahnya mempunyai industry batik sendiri. Ada pula yang mempunyai tempat belajar pembuatan batik bagi orang-orang awam.

Hal tersebut oleh pemerintah kota setempat dikembangkan menjadi destinasi wisata khas Surakarta. Berkembangnya industry batik juga meningkatkan pariwisata local maupun domestik. Efeknya adalah perekonomian di kampung tersebut akan meningkat pesat diiringi dengan banyaknya jumlah pengunjung yang datang. Semakin banyak para wisatawan yang datang ke Surakarta, perekonomian akan meningkat karena terjadi hubungan social ekonomi dan budaya di daerah tersebut.

\section{B. METODOLOGI PENELITIAN}

Kajian ini akan membahas tentang seni batik yang ada di Surakarta dalam upaya mendukung peningkatan pariwisata yang ada di Surakarta sendiri. Untuk menganalisis isi jurnal-jurnal yang sudah diterbitkan, kajian ini menggunakan pendekatan deskriptif kualitatif. Menurut Sugiyono (2018:15) bahwa penelitian kaulitatif deskriptif adalah metode penelitian yang berlandaskan pada filsafat postpositivisme yang biasanya digunakan untuk meneliti pada kondisi objektif dimana peneliti berperan sebagai instrument kunci.

Sementara itu, Nawawi dan Martini (1994:73) mendefinisikan metode deskriptif sebagai metode yang melukiskan suatu keadaan objektif atau peristiwa tertentu berdasarkan fakta-fakta yang tampak atau sebagaimana mestinya yang kemudian diiringi dengan upaya pengambilan kesimpulan umum berdasarkan fakta-fakta historis tersebut, berdasarkan pemaparan Dadang Supardan (2000: 103), studi deskriptis analitis adalah suatu penelitian yang tertuju pada penelaan masalah yang ada sekarang.

Sedangkan menurut Djam'an Satori (2011: 23) mengungkapkan bahwa penelitian kualitatif dilakukan karena peneliti ingin mengeksplor fenomena-fenomena yang tidak dapat dikuantifikasikan yang bersifat deskriptif seperti proses suatu langkah 
Peran Kesenian Batik Lokal di Surakarta untuk Meningkatkan Destinasi Wisatawan Lokal dan Domestik (Isa Maryati )

kerja, formula suatu resep, pengertian-pengertian tentang suatu konsep yang beragam, karakteristik suatu barang dan jasa, gambar-gambar, gaya-gaya, tata cara suatu budaya, model fisik suatu artifak dan lain sebagainya. Nana Syaodih (2011:73) juga mengungkapkan penelitian deskriptid ditujukan untuk mendeskripsikan dan menggambarkan fenomena-fenomena yang ada, baik bersifat alamiah maupun rekayasa manusia, yang lebih memperhatikan mengenai karakteristik, kualitas, keterkaitan antar kegiatan.

Penelitian deskriptif kualitatif sesuai dengan tema nilai-nilai budaya lokal yakni seni batik yang ada di Surakarta. Peneliti akan menggunakan pendekatan tersebut untuk mengungkap peran dari seni batik sendiri. Karena pada dasarnya di daerah Surakarta banyak menjamur usaha batik. Batik yang paling popular di Surakarta adalah Batik Kauman dan Batik Laweyan. Selain memproduksi kain batik, batik Kauman dan batik Laweyan juga mempunyai outlet untuk pengunjung dan tempat belajar membatik. Walaupun tidak semua pengusaha batik mempunyai fasilitas wisata bagi para pengunjung yang ingin membuat batik.

\section{HASIL DAN PEMBAHASAN}

\section{Kampung Batik Laweyan di Surakarta}

Berdasarkan data dari Pemerintah daerah Kota Surakarta (2012), kelurahan Laweyan merupakan Kelurahan yang terletak di Kecamatan Laweyan Kota Surakarta dengan potensi sebagai desa wisata. Kelurahan Laweyan dibagi atas 3 RW dan 10 RT dengan luas wilayah 4,2 Ha. Mangedaby, Ratih Sari dan Setioko (2017: 28-34) mengungkapkan bahwa masyarakat Laweyan bukanlah keturunan bangsawan, tetapi karena mempunyai hubungan yang erat dengan keraton melalui perdagangan batik serta didukung dengan kekayaan yang ada, maka corak pemukiman khususnya milik para saudagar batik banyak dipengaruhi oleh corak pemukiman bangsawan Jawa. Bangunan rumah saudagar biasanya terdiri dari pendopo, ndalem, sentong, gandok, pavilion, pabrik, beteng, regol, halaman depan rumah yang cukup luas dengan orientasi bangunan menghadap utara selatan.

Soedarmono (2014) dalam Sariyatun (2010) menuliskan bahwa Laweyan telah dikenal sebagai pusat batik sejak awal abad kedua puluh. Terletak sekitar $4 \mathrm{~km}$ dari pusat Kota Surakarta. Semasa Kerajaan, Laweyan dibagi menjadi dua wilayah, yaitu: 
Laweyan Barat dan Laweyan Timur. Kehidupan social budaya Laweyan Barat telah dibentuk dengan fasilitas yang disediakan oleh raja. Sebagian besar orang yang tinggal di Laweyan Timur bekerja di pasar dan sebagian besar dari mereka adalah pedagang dan produsen batik. Di Laweyan, pasar adalah pusat perdagangan tetapi sekarang sudah berubah menjadi dua kampung yakni Kampung Lor dan Kampung Kidul.

Erma, Nursiam dan Zulfikar (2015) juga mengungkapkan tentang Kampung Laweyan. Mereka mengungkapkan bahwa Kampung Laweyan memiliki kampung batik yang paling tua di Indonesia yaitu Kampung Batik Laweyan. Kampung ini merupakan sentra industry batik tradisional. Kehidupan masyarakatnya sebagian besar masih bertahan dengan produksi batik, seolah-olah mereka menunjukkan eksistensinya dengan lingkungan sekitarnya. Produksi batik ini dipasarkan sebagian besar di dalam negeri. Usaha batik laweyan juga dinilai berkembang dengan indikasi semakin bertambahnya jumlah pengusaha, ruang Panjang serta peredaran usaha mereka.

\section{Makna Filosofis Batik dan Motif Seni Batik Surakarta}

Sariyatun (2006) mengungkapkan batik Surakarta terkenal keindahannya secara visual dan secara tersurat mengandung nilai filosofis yang tinggi yang dapat menjadi daya tarik pariwisata. Pada dasarnya batik yang ada si Surakarta mempunyai motifmotif yang menarik sehingga banyak pembeli yang ingin memiliki bahkan banyak juga masyarakta Solo yang mengkoleksi batik.

Menurut Soedardjo (1990), keindahan visual dalam batik disebut sebagai keindahan estetika dapat dilihat dari motif yang tetap dalam bidang dan tata warna yang harmonis. Sariyatun (2018), keindahan filosofis atau keindahan jiwa adalah suatu rasa indah yang diperoleh dari susunan arti lambing yang membuat gambar sesuai dengan paham yang dimengerti. Keindahan ini merupakan perpaduan yang menggambarkan pegangan hidup pada waktu itu, karena aspek-aspek kehidupan manusia sedikit banyak sudah terlukiskan dalam ornament motif batik.

Sariyatun (2018) menerangkan bahwa simbolisme motif batik klasik merupakan kenyataan dari gejala "superorganik", yaitu realitas yang divisualkan dalam berkesenian. Menurut Suzanne K. Lenger sebagai bentuk "virtualitas" ialah sesuatu yang ada tetapi tidak dapat diraba hanya dapat dirasakan keberadaannya. Tanda lahirian secara Teknik dapat ditransformasikan ke dalam beberapa jenis motif batik. dengan demikian pola hias batik di samping mempunyai bentuk dan susunan yang khusus, juga 
Peran Kesenian Batik Lokal di Surakarta untuk Meningkatkan Destinasi Wisatawan Lokal dan Domestik (Isa Maryati )

memiliki makna simbolis. Keindahan pola hias batik dapat dilihat dari keindahan visual dan keindahan filosofis.

Bastomi (1992), menjelaskan lambing dalam budaya Jawa merupakan pertalian budi pekerti manusia dalam konteks kehidupan merupakan acuan untuk beperilaku dan berfungsi sebagai etunjuk yang memberi arah terhadap pengalaman hidup manusia. Sariyatun (2018) mengungkapkan bahwa symbol pada umumnya bermakna sebagai piwulang atau pameling.

Saiyatun (2018) menjelaskan bahwa setiap penciptaan motif batik selalu memiliki makna simbolis berdasarkan falsafah Jawa, karen aitu pemakainan motif didasarkan pada dua hal, yakni 1) kedudukan social seseorang di dalam masyarakat, 2) pada kesempatan atau peristiwa apa batik dipergunakan tergantung dari makna dan harapan yang terkandung pada ragam hias batik tersebut. hal ini menjadikan batik klasik mengandung tuntunan dan tatanan. Sebagian idiom makna simbolis motif-motif batik klasik mempunyai kandungan muatan kearifan local dan dianggap dapat melampaui jamannya. Sebagai contoh adalah motif batik Semen, Truntum, dan Sidoluhur.

Pemakaian motif batik klasik berkaitan dengan hal-hal yang sifatnya transcendental atau berlatar bekalang magis, dan mengandung tuntunan, sebagai contoh larangan bagi pengantin tidak memakai kain batik motif Parang Rusak dimaknai dapat mengakibatkan rusaknya tali perkawinan atau perceraian. Daubanton (1992) dan philip Kitley (1991) dalam Sariyatun (2010) menjelaskan tentang Industry perkembangan batik, mengalami perkembangan yang pesat pada awal abad kedua puluh setelah ditemukannya perangko batik, menggantikan canting. Orientasi produk batik Laweyan ditandai oleh produksi batik untuk dipakai atau "batik sandang" pada tahun 1925 dan Batik Tedjo pada tahun 1956.

Wibisono (1992) mengungkapkan bahwa kain batik merupakan hasil karya seni budaya yang tinggi serta mengandung nilai-nilai keindahan, visual, maupun spiritual. Kain batik mempunyai banyak motif salah satunya yang diungkapkan oleh Sariyatun (2013) adalah batik dengan motif burung yang disebut "Gurda". Gurda adalah perlambang kebebasan jiwa yang tidak mau dijajah dan lambing kegagahan dan kekuatan. Motif batik Sido Luhur, melambangkan kemuliaan dan keluhuran budi pekerti. Motif batik Semen Ramawijaya mencerminkan ajaran budaya jawa yang disebut Hasta Bhrata, 
Selain motif batik diatas, motif batik tradisional Kawung juga sangat popular di kalangan pencinta batik. Pramono (2013) menerangkan motif batik tradisional Kawung mempunyai makna bahwa si pemilik diharapkan dapat berguna bagi orang banyak, diibaratkan seperti pohon Kawung atau Aren dari akar, batang, daun ijuk, nira dan buahnya semua berguna bagi manusia. Batik tradisional sebagai warisan budaya mengandung nilai kearifan yang menarik untuk diteliti dari segi proses, motif, warna, ornamen, dan fungsi dari sehelai batik.

Sultan Hamengku Buwono VIII dalam Pramono (2013) membakukan aturan tata cara penggunaan batik. Salah satu batik yang digunakan dalam berbagai event dan pakaian kebesaran adalah motif Parang Rusak yang dibedakan atas tiga bentuk motif, yaitu: Parang Rusak Barong, Parang Gedreh, dan Parang Klitik. Ukuran motifnya ditentukan bahwa motif Parang Barong lebih besar dari ukuran motif Parang Gedreh yang besarnya tidak boleh lebih dari empat sentimeter yang ditarik garis tegak lurus diantara barisan unsur motif mlinjon.

Pada dasarnya makna filosofis dari motif batik berbeda-beda. Kental dengan adat Jawi, motif tersebut sebenarnya mempunyai makna yang baik bagi kelangsungan hidup masyarakat Jawa itu sendiri. Dengan begitu kehidupan masyarakat Jawa diharapkan tertata sesuai dengan filosofi dari motif batik itu sendiri.

\section{Kesenian Batik Lokal Untuk Meningkatkan Pariwisata di Surakarta}

Hasil penelitian dari Ibnu Majah (2015) mengungkapkan bahwa kota Surakarta terutama Kampung Laweyan mengalami krisis pada tahun 1970-an. Penurunan ekonomi puncaknya terjadi pada tahun 1997 saat terjadi krisis ekonomi di berbagai wilayah di Indonesia. Banyak pengusaha batik yang gulung tikar dan beralih profesi ke pekerjaan lainnya. Tetapi lambat laun perekonomian Indonesia terutama di Surakarta mulai bangkit berkat adanya wisata batik.

Sejalan dengan hasil dari penelitian yang dilakukan oleh Sariyatun dkk (2006) tentang revitalisasi seni batik, diharapkan mampu memberikan manfaat kepada berbagai elemen pemangku kepentingan (stakeholder) pariwisata termasuk swasta, masyarakat setempat, wisatawan dan pemerintah khususnya Pemerintah Kota Surakarta. Manfaat yang diharapkan dari penelitian tersebut adalah memberikan sumbangan berharga bagi pengembangan pariwisata berbasis masyarakat dan interpretasi melalui berbagai produk wisata khusus ke obyek-obyek wisata di Kota Surakarta yang memiliki warisan budaya 
Peran Kesenian Batik Lokal di Surakarta untuk Meningkatkan Destinasi Wisatawan Lokal dan Domestik (Isa Maryati )

berupa potensi dalam rangka mengantisipasi pergeseran minat wisatawan yang cenderung meninggalkan bentuk-bentuk wisata konvensional dan mencari orisinalitas dan pengalaman baru di daerah tujuan wisata termasuk daya Tarik wisata yang unik dan daya Tarik wisata yang memiliki latar belakang budaya.

Sariyatun dkk juga mengatakan pengembangan pariwisata berbasis masyarakat melalui berbagai produk wisata minat khusus ke boyek-obyek wisata batik dalam rangka memberikan manfaat dalam bentuk multiplier effect sehingga mampu memberikan pendapatan tambahan kepada masyarakat. Pada penelitian tahap kedua, Sariyatun dkk (2007) mengungkapkan bahwa revitalisasi seni batik klasik melalui interpretasi akan memberikan berbagai manfaat, salah satunya adalah menjadi ujung tombak promosi obyek dan daya Tarik wisata sehingga mendukung pengembangan pariwisata daerah, khususnya pariwisata kota Surakarta. Dengan meningkatnya pariwisata di wilayah Surakarta, secara tidak langsung mengembangkan perekonomian di wilayah tersebut. selain itu kesejahteraan masyarakat Surakarta meningkat.

Batik menjadi salah satu komoditas yang penting di kota Surakarta. Hal tersebut juga diungkapkan oleh istijabatul (2007) bahwa dalam merumuskan strategi pengembangan Pasar tradisional di Kota Surakarta hal yang harus diperhatikan adalah jenis barang dagangan yang menjadi kekhasan local kota Surakarta yang meliputi komoditas local salah satunya adalah batik. batik adalah ikon yang menyumbang banyak perekonomian Surakarta. Perdagangan batik merajalela sampai sekarang sehingga seni batik menjadi salah satu icon pariwisata Surakarta.

Selain penduduk pribumi, pedagang batik dari Cina juga tumbuh menjamur di Kota ini. Hal ini disampaikan oleh sariyatun (2001), pengusaha batik pribumi berhubungan baik dengan pedagang perantara Cina karena batas keuntungan yang diambil tidak berlebihan. Sejak tahun 1982 orang-orang Cina mulai menembus indutsri Batik melalui pengawasan atas suplai bahan mentah dan produksi barang jadi. Mereka menguasai pasar di luar Surakarta dan Jawa Tengah. Usaha mereka semakin menjadi setelah ditemukan Teknik cap dan pewarna sintetis. Ragam hias batik Cina Surakarta merupakan perpaduan bati pesisir dan batik Vostenlanden. Hubungan antara majikan dan burh sangat baik karena masyarakat Cina Surakarta dikenal sebagai Cina yang halus. 


\section{SIMPULAN}

Kampung Laweyan memiliki kampung batik yang paling tua di Indonesia yaitu Kampung Batik Laweyan. Kampung ini merupakan sentra industry batik tradisional. Kehidupan masyarakatnya sebagian besar masih bertahan dengan produksi batik, seolah-olah mereka menunjukkan eksistensinya dengan lingkungan sekitarnya. Produksi batik ini dipasarkan sebagian besar di dalam negeri. Usaha batik laweyan juga dinilai berkembang dengan indikasi semakin bertambahnya jumlah pengusaha, ruang Panjang serta peredaran usaha mereka.

Sariyatun (2006) mengungkapkan batik Surakarta terkenal keindahannya secara visual dan secara tersurat mengandung nilai filosofis yang tinggi yang dapat menjadi daya tarik pariwisata. Pada dasarnya batik yang ada si Surakarta mempunyai motifmotif yang menarik sehingga banyak pembeli yang ingin memiliki bahkan banyak juga masyarakta Solo yang mengkoleksi batik.

Wibisono (1992) mengungkapkan bahwa kain batik merupakan hasil karya seni budaya yang tinggi serta mengandung nilai-nilai keindahan, visual, maupun spiritual. Kain batik mempunyai banyak motif salah satunya yang diungkapkan oleh Sariyatun (2013) adalah batik dengan motif burung yang disebut "Gurda". Gurda adalah perlambang kebebasan jiwa yang tidak mau dijajah dan lambing kegagahan dan kekuatan. Motif batik Sido Luhur, melambangkan kemuliaan dan keluhuran budi pekerti. Motif batik Semen Ramawijaya mencerminkan ajaran budaya jawa yang disebut Hasta Bhrata,

Sariyatun dkk juga mengatakan pengembangan pariwisata berbasis masyarakat melalui berbagai produk wisata minat khusus ke boyek-obyek wisata batik dalam rangka memberikan manfaat dalam bentuk multiplier effect sehingga mampu memberikan pendapatan tambahan kepada masyarakat. Pada penelitian tahap kedua, Sariyatun dkk (2007) mengungkapkan bahwa revitalisasi seni batik klasik melalui interpretasi akan memberikan berbagai manfaat, salah satunya adalah menjadi ujung tombak promosi obyek dan daya Tarik wisata sehingga mendukung pengembangan pariwisata daerah, khususnya pariwisata kota Surakarta. Dengan meningkatnya pariwisata di wilayah Surakarta, secara tidak langsung mengembangkan perekonomian di wilayah tersebut. selain itu kesejahteraan masyarakat Surakarta meningkat. 
Peran Kesenian Batik Lokal di Surakarta untuk Meningkatkan Destinasi Wisatawan Lokal dan Domestik (Isa Maryati )

\section{DAFTAR PUSTAKA}

Dadang Supardan, Pengantar Ilmu Sosial Sebuah Kajian Pendekatan Struktural, Jakarta: Bumi Aksara.

Erma Setiawati, dkk. 2015. Pengembagan Komoditas Batik: Determinasi Budaya Ekonomi dan Perubahan Struktur Kebijakan Terhadap Perkembangan Usaha Ekonoi Lokal Surakarta. Jurnal Ekonomi dan Bisnis, Volume XVIII No. 1 Apil 2015.

Eva Artmey dkk. 2017. Pengaruh Desa Wisata Kampoeng Batik Laweyan Terhadap Fungsi Pemukiman di Kelurahan Laweyan Kota Surakarta. Semarang: Undip. Jurnal Teknik, 38 (1), 2017, 28-34.

Hadari Nawawi \& Mimi Martini, 1994, Penelitian Terapan, Yogyakarta: Gajahmada University.

Ibnu Majah. 2015. Laweyan dalam Periode Krisis Ekonomi hingga menjadi Kawasan Wisata Sentra Industri Batik Tahun 1998-2004. Jurnal of Indonesian History Vol. 3 No. 2 tahun 2015 (ISSN 2252-6633) hlm. 29-36.

Kartini Parmono. 2013. Nilai Kearifan Lokal dalam Batik Tradisional Kawung. Yogyakarta: UGM. Jurnal Filsafat Vol. 23, Nomor 2, Agustus 2013.

Nana Syaodih Sukmadinata. (2011). Metode Penelitian Pendidikan. Bandung: PT Remaja Rosdakarya.

Sariyatun. 2001. Usaha Batik Masyarakat Cina di Surakarta Tahun 1900-1930. Yogyakarta: UGM.

Sariyatun. 2006. Pengembangan Model Revitalisasi Seni Batik Klasik Melalui Interpretasi Sebagai Upaya Untuk Melestarikan Warisan Budaya dan Mendukung Pengembangan Pariwisata di Surakarta. Surakarta: UNS.

Sariyatun. 2007. Model Revitalisasi Seni Batik Klasik sebagai Upaya Untuk Melestarikan Warisan Budaya dan Mendukung Pengembangan Pariwisata di Surakarta. Surakarta: LPPM UNS.

Sariyatun. 2018. Pantulan Budaya Lokal Makna Filosofis dan Simbolisme Motif Bati Klasik Untuk Penguatan Pendidikan Karakter. Surakarta: UNS. JPSI, Vol. 1 No 12018.

Sugiyono. 2013. Metode Penelitian Pendidikan Pendekatan Kuantitatif, Kualitatif, dan $R \& D$. Bandung: Alfabeta. 